\title{
Pemberian Tepung Daun Kelor (Moringa oleifera L) Melalui Pakan Sebagai PencegahanTerhadap Infeksi Bakteri Edwarsiella Ictaluri Pada Ikan Patin (Pangasius hypopthalmus)
}

\author{
${ }^{1)}$ Yuda Saputra, ${ }^{2}$ Syarizal, ${ }^{2}$ Safratilofa, dan ${ }^{3)}$ Edy Barkat Kholidin \\ ${ }^{1)}$ Alumni Prodi Budidaya Perairan Fakultas Pertanian Universitas Batanghari Jambi \\ 2) Prodi Budidaya Perairan Fakultas Pertanian Universitas Batanghari Jambi \\ ${ }^{3)}$ Pembimbing Lapangan LAB kesehatan ikan, BPBAT Jambi. \\ Program Studi Budidaya Perairan, Fakultas Pertanian Universitas Batanghari \\ J1. Slamet Riyadi, Broni Jambi, 36122. Telp. +6074160103 \\ ${ }^{1)}$ e-mail korespondensi : yudasaputra0304@gmail.com
}

\begin{abstract}
The purpose of this study was to determine the effect of giving Moringa oliefera L leaf meal through feed as an antibacterial to prevent infection with E.ictaluri bacteria in catfish (Pangasius hypopthalmus). This research was conducted from March 2020 to April 2020 at the Fish Health Laboratory, Freshwater Aquaculture Fisheries Center (BPBAT) Jambi. The research method used was a completely randomized design with five treatments and three replications. Catfish were fed for 14 days with treatment feed with each treatment (A. 5\% / kg feed), (B. $10 \% / \mathrm{kg} \mathrm{feed),} \mathrm{(C.} \mathrm{15 \%} \mathrm{/} \mathrm{kg} \mathrm{feed),(D.Commercial} \mathrm{feed)}$ and (E. Commercial feed). and on the 16th day the fish were injected with the Edwarsiella ictaluri bacteria, and survival was observed from day 16 to day 26. The results showed that treatment of moringa leaf meal (C. $15 \% / \mathrm{kg}$ of feed), could prevent bacterial infection E. ictaluri in catfish with the highest survival rate reaching $66.67 \%$, fish growth of 5.78 grams / head, and feed conversion of $0.18 \% / \mathrm{kg}$ of feed.
\end{abstract}

Keywords: Moringa oliefera L, Edwarsiella ictaluri, Patin Fish (Pangasius hypopthalmus)

\begin{abstract}
Abstrak. Tujuan penelitian ini adalah untuk mengetahui pengaruh pemberian tepung daun kelor (Moringa oliefera L) melalui pakan sebagai anti bakteri untuk mencegah infeksi bakteri E.ictaluri pada ikan patin (Pangasius hypopthalmus). Penelitian ini dilakukan sejak Maret 2020 sampai April 2020 di Laboratorium kesehatan ikan, Balai Perikanan Budidaya Air Tawar (BPBAT) Jambi. Metode penelitian yang digunakan adalah Rancangan Acak Lengkap dengan lima perlakuan dan tiga ulangan. Ikan patin diberi makan selama 14 hari dengan pakan perlakuan dengan masing - masing perlakuan (A. $5 \% / \mathrm{kg}$ pakan), (B. 10\%/kg pakan), (C. $15 \% / \mathrm{kg}$ pakan), (D. Pakan komersial) dan (E. Pakan komersial). dan pada hari ke 16 ikan diinjeksi bakteri Edwarsiella ictaluri, dan pengamatan kelangsungan hidup dari hari ke 16 sampai hari ke 26. Hasil penelitian menunjukkan bahwa perlakuan tepung daun kelor perlakuan (C. $15 \% / \mathrm{kg}$ pakan), dapat mencegah terjadinya infeksi bakteri E.ictaluri pada ikan patin dengan tingkat kelangsungan hidup tertinggi mencapai $66,67 \%$, pertumbuhan ikan 5,78 gram/ekor, dan konversi pakan $0,18 \% / \mathrm{kg}$ pakan.

Kata Kunci : Moringa oliefera L, Edwarsiella ictaluri, Pangasius hypopthalmus, pakan
\end{abstract}

\section{PENDAHULUAN}

Ikan patin (Pangasius hypophthalmus) merupakan salah satu komoditas ikan air tawar yang telah lama dikenal masyarakat dan memiliki pangsa pasar yang cukup luas meliputi pasar domestik dan ekspor, meskipun ikan patin ini memiliki nilai ekonomis yang tinggi dipasaran, tetapi ikan ini memiliki kendala dalam budidaya, yaitu kendala yang di hadapi rentannya terserang bakteri (Gustiano dalam Jadmiko, 2016). Salah satu bakteri yang sering menyerang ikan patin adalah bakteri Edwardsiella ictaluri, yang dapat menyebabkan penyakit Enteric septicemia of catfish (ESC). ESC dapat menyebabkan kematian ikan patin sampai $>50 \%$ (Wiwik et.al 2016). Upaya pencegahan untuk mengatasi serangan bakteri E.ictaluri dapat menggunakan fitofarmaka. Fitofarmaka memiliki efek samping yang relatif lebih sedikit dari pada obat kimia modern, Sari dalam Emilda (2018). Salah satu tanaman yang dapat dijadikan sebagai bahan fitofarmaka adalah daun kelor. (Rajanandh dalam Valent, 2017) daun kelor memiliki kandungan antioksidan diantaranya, saponin, alkaloid, fitosterol, tanin, fenolik dan flavonoid. Hal ini diperkut dengan hasil penelitian Oluduro, (2011) menjelaskan bahwa daun kelor dapat menghambat beberapa bakteri seperti Streptococcus sp., Pseudomonas fluoroscens, Proteus mirabilis. Dalam penelitian ini digunakan tepung daun kelor untuk mencegah infeksi bakteri E. ictaluri pada ikan patin. Tujuan penelitian ini adalah untuk mengetahui pengaruh pemberian tepung daun kelor (Moringa oliefera L) melalui pakan sebagai anti bakteri untuk mencegah infeksi bakteri E.ictaluri pada ikan patin (Pangasius hypopthalmus) 
Yuda Saputra, Syarizal, Safratilofa, dan Edy Barkat Kholidin. Pemberian Tepung Daun Kelor (Moringa oleifera L) Melalui Pakan Sebagai PencegahanTerhadap Infeksi Bakteri Edwarsiella Ictaluri Pada Ikan Patin (Pangasius hypopthalmus)

\section{Waktu dan Tempat Penelitian}

\section{METODOLOGI PENELITIAN}

Penelitian ini di laksanakan pada bulan Maret - April 2020, bertempat di Laboratorium Balai Perikanan Budidaya Air Tawar (BPBAT), Sungai Gelam Jambi.

\section{Alat dan bahan}

Alat-alat penelitian yang digunakan meliputi bak plastik berukuran $40 \mathrm{~cm}$ x $40 \mathrm{~cm}$ x $30 \mathrm{~cm}$ sebanyak 15 buah, saringan 1 buah, blender 1 buah, blower, timbangan digital, spuit, mikroskop, tabung reaksi, pena, buku, mistar, termometer , $\mathrm{pH}$ meter, DO meter. Bahan - bahan penelitian meliputi ikan uji, daun kelor, pakan komersial PF 0 dan bahan-bahan lain yang di perlukan.

\section{Rancangan Penelitian}

Pada penelitian ini rancangan yang digunakan adalah Rancangan Acak Lengkap (RAL), dengan 5 perlakuan dan 3 kali ulangan, perlakuan pada penelitian ini dapat dilihat pada Tabel. 1.

Tabel. 1 Pemberian tepung daun kelor terhadap pencegahan bakteri E.ictaluri

\section{Perlakuan}

A.

B.

C.

D.

E.

\section{Tepung Daun Kelor}

Penambahan tepung daun kelor 5\%/kg pakan + injeksi bakteri E. ictaluri

Penambahan tepung daun kelor $10 \% / \mathrm{kg}$ pakan + injeksi bakteri E. ictaluri

Penambahan tepung daun kelor $15 \% / \mathrm{kg}$ pakan + injeksi bakteri E. ictaluri

Kontrol Positif $=$ Pakan komersial + injeksi bakteri E. ictaluri

Kontrol Negatif $=$ Pakan komersial + diinjeksi dengan $\mathrm{NaCl} 0,9$

Tabel 2. Rancangan penelitian pemberian tepung daun kelor (Moringa oliefera L) melalui pakan sebagai pencegahan terhadap infeksi bakteri Edwarsiella ictaluri pada ikan patin (Pangasius hypopthalmus)

1. Kontrol (-)

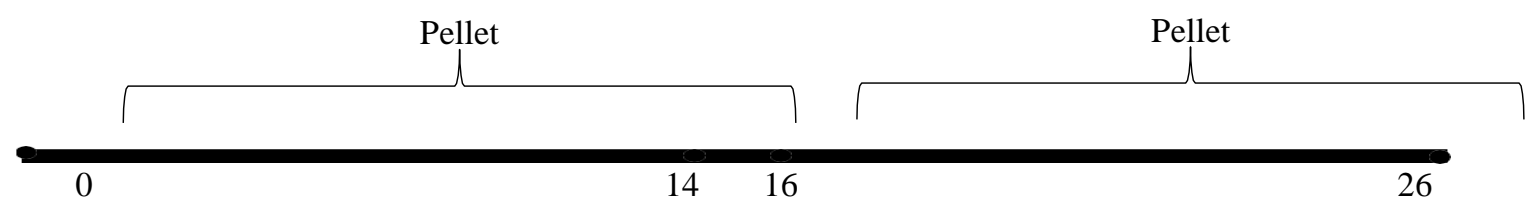

2. Kontrol (+)

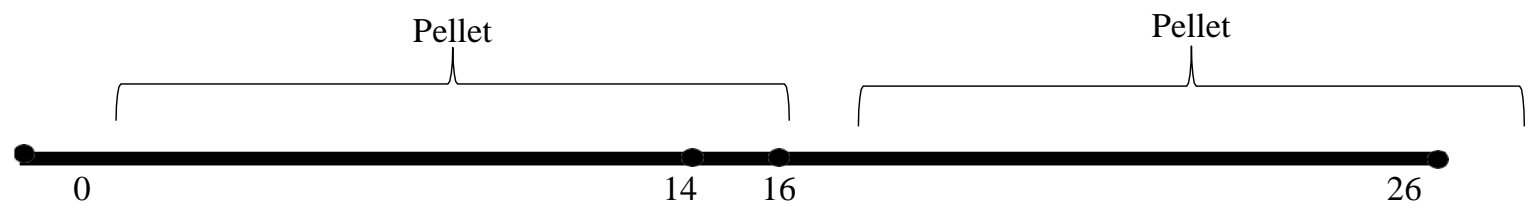

3. Perlakuan A

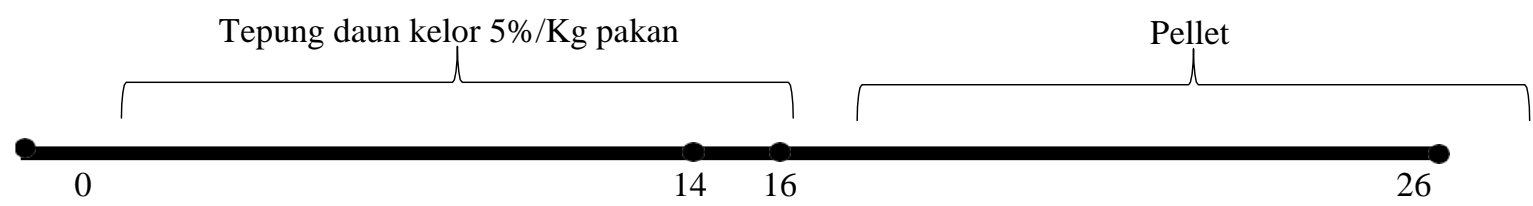

4. Perlakuan B

Tepung daun kelor $10 \% / \mathrm{Kg}$ pakan
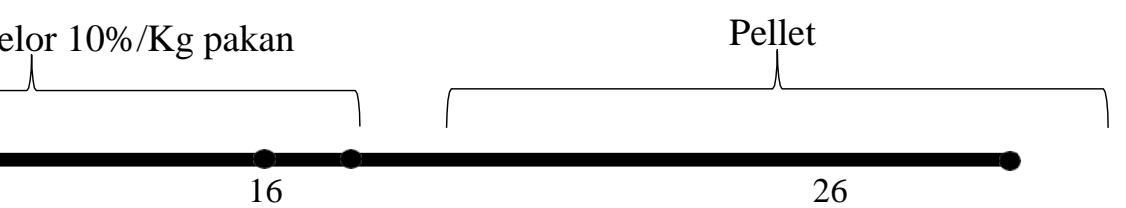

0
5. Perlakuan C

Tepung daun kelor $15 \% / \mathrm{Kg}$ pakan

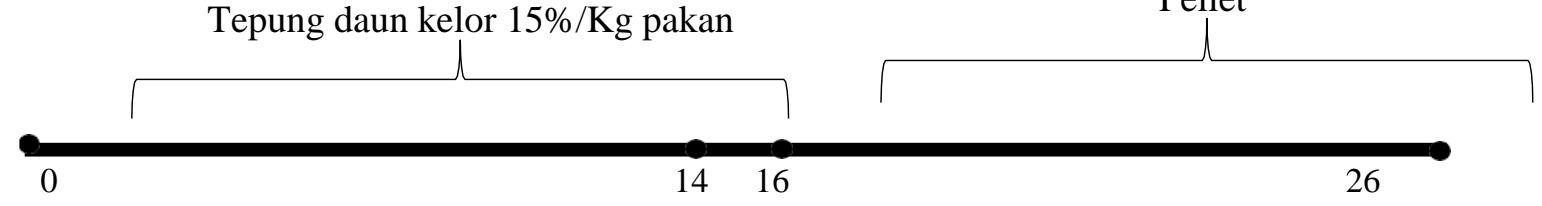


Data yang diperoleh dianalisis dengan menggunakan analisis ragam dengan tingkat kepercayaan 95\%. Untuk melihat perbedaan perlakuan maka dilakukan uji lanjut dengan uji Duncan's Multiple Range dengan menggunakan program komputer SPSS 20.

\section{Prosedur Penelitian \\ Persiapan Wadah}

Wadah uji yang digunakan adalah bak plastik yang berukuran 40x40x30cm, sebanyak 15 buah, sebelum digunakan wadah uji terlebih dahulu dicuci sampai bersih lalu di keringkan, setelah kering wadah uji dimasukan air dengan volume 10 liter. Air yang digunakan berasal dari sumur, sebelum dimasukkan kedalam wadah uji, air terlebih dahulu diendapkan didalam tandon, supaya kotoran-kotoran yang ada di air dapat mengendap kedasar tandon.

\section{Persiapan Ikan}

Ikan yang digunakan dalam kegiatan penelitian yaitu ikan patin (P. hypopthalmus) dengan bobot rerata ikan awal $\pm 5,46$ /gram, ikan uji diperoleh dari BPBAT (Balai Perikanan Budidaya Air Tawar) Sungai Gelam. Jumlah ikan yang digunakan sebanyak 10 ekor/wadah. Total keseluruhan ikan yang dibutuhkan sebanyak 150 ekor. Sebelum diberi perlakuan ikan terlebih dahulu di aklimatisasi selama 1 minggu.

\section{Persiapan Bakteri}

Bakteri yang didapat berasal dari koleksi BPBAT (Balai Perikanan Budidaya Air Tawar) Sungai Gelam, yang telah diidentifikasi, yang menyatakan bahwa bakteri yang digunakan bakteri E.ictaluri.

\section{Pembuatan Tepung Daun Kelor}

Daun kelor yang digunakan dalam penelitian ini adalah sebanyak 1500 gram, daun kelor di cuci dengan air bersih terlebih dahulu kemudian di keringkan dengan menggunakan oven dengan suhu $45^{\circ} \mathrm{C}$ selama 72 jam, daun kelor yang telah kering dihaluskan menggunakan blender hingga menjadi tepung dan tepung telah dapat digunakan.

\section{Parameter Penelitian}

Pertumbuhan Bobot Mutlak

Menurut Effendi (1997) Pertumbuhan bobot mutlak dapat di hitung dengan rumus :

$$
\mathrm{Wm}=\mathrm{Wt}-\mathrm{Wo}
$$

Keterangan:

$\mathrm{Wm}=$ Pertumbuhan berat mutlak

$\mathrm{Wt}=$ Berat ikan uji pada akhir pemeliharaan

$\mathrm{Wo}=$ Berat ikan uji pada awal pemeliharaan

\section{Rasio Konversi Pakan (FCR)}

Rasio konversi pakan dapat dihitung dengan menggunakan rumus (Aryanto et al.,2007) :

$$
\mathrm{FCR}=\frac{\text { Jumlah pakan y ang diberikan }(\mathrm{g})}{\text { Pertambah an bobot }(\mathrm{g})}
$$

\section{Tingkat Kelangsungan Hidup Atau Survival Rate (SR)}

Menurut Efendie dalam Tiara, (2018) Kelangsungan hidup dapat dihitung dengan rumus:

$$
\mathrm{SR}=\frac{N t}{N o} \times 100 \%
$$

Keterangan :

$\mathrm{SR}=$ Kelangsungan hidup $(\%)$

$\mathrm{Nt}=$ Jumlah ikan yang hidup pada akhir pemeliharaan (ekor)

No = Jumlah ikan yang ditebar pada awal pemeliharaan (ekor)

\section{Gejala Klinis}

Pengamatan terhadap gejala klinis yang dilakukan yaitu pada bagian internal dan eksternal pada ikan patin. 


\section{Kelangsungan Hidup}

\section{HASIL DAN PEMBAHASAN}

Pengamatan kelangsungan hidup ikan patin yang telah diinjeksi dengan bakteri E.ictaluri dilakukan selama 10 hari pengamatan mulai dari hari ke-16 sampai ke-26 pemeliharaan, setelah diinjeksi bakteri E.ictaluri. Hasil data rata-rata pengamatan dapat dilihat pada Tabel. 3 .

Tabel. 3 Kelangsungan Hidup Ikan Patin (P. hypopthalmus) Setelah Diberi Perlakuan Daun Kelor (Moringa oliefera L) Yang Diinjeksi Dengan Bakteri E.ictaluri

\begin{tabular}{ccc}
\hline Perlakuan & $\begin{array}{c}\text { Rerata } \\
\text { (Daun Kelor)\% }\end{array}$ & Notasi \\
A (5\%) & 63,33 & Stastistik \\
B (10\%) & 60,00 & $\mathrm{~b}$ \\
C (15\%) & 66,67 & $\mathrm{c}$ \\
D (KP) & 46,67 & $\mathrm{a}$ \\
E (KN) & 100 & $\mathrm{~d}$ \\
\hline
\end{tabular}

Catatan : Huruf yang berbeda pada kolom notasi menunjukkan berbeda nyata $(\mathrm{P}>0,05)$

Pada Tabel. 3 kelangsungan hidup tertinggi ikan patin terdapat pada perlakuan E dengan kelangsungan hidup $100 \%$, karena perlakuan E tidak dinjeksi dengan bakteri melainkan diinjeksi dengan larutan $\mathrm{NaCl} 0,9 \%$, perlakuan yang diinjeksi dengan bakteri dengan kelangsungan hidup tertinggi terdapat pada perlakuan $\mathrm{C}$ (15\%/kg pakan) dengan kelangsungan hidup sebesar 66,67\%. Tingginya kelangsungan hidup pada perlakuan $\mathrm{C}$ diduga dikarenakan dosis bahan aktif pada daun kelor yang masuk ke dalam tubuh ikan lebih banyak dibandingkan perlakuan A dan B, selain itu kandungan bahan aktif daun kelor pada perlakuan $C$ sudah mencukupi untuk menghambat pertumbuhan bakteri E.ictaluri. Kandungan bahan aktif yang terdapat pada daun kelor seperti flavonoid, alkaloid, fenol yang juga dapat menghambat aktivitas bakteri. Pandey dalam Lusi,(2016). Menurut Ngajow dalam Safratilofa, (2018) Flavonoid memiliki mekanisme sebagai antibakteri dengan membentuk kompleks protein ekstraselular sehingga dapat merusak membran sel bakteri, menghambat sintesis DNA dan RNA, dan mengganggu metabolisme sel. Pemberian tepung daun kelor pada pakan perlakuan A (5\%/kg pakan) dengan kelangsungan hidup 63,33\% dan B (10\%/kg pakan) 60,00\% mampu menghasilkan kelangsungan hidup ikan patin yang tidak berbeda nyata di setiap perlakuan, diduga jumlah tepung yang ditambahkan lebih sedikit dari pada perlakuan $\mathrm{C}$, untuk perlakuan D memiliki rerata kelangsungan hidup terendah sebesar $46,67 \%$, karena perlakuan D tidak diberikan tepung daun kelor sehingga tidak dapat menghambat pertumbuhan bakteri E.ictaluri. Menurut Wahjuningrum et al. (2012) menyatakan bahwa nilai persentase mortalitas pada perlakuan D lebih tinggi dibandingkan perlakuan yang diberi bahan fitofarmaka. Hal ini menunjukkan bahwa pemberian bahan fitofarmaka yang dicampur dengan pakan dapat menghambat infeksi bakteri E.ictaluri serta dapat meningkatkan sistem kekebalan tubuh ikan.

\section{Gejala Klinis}

Gejala klinis yang amati setelah dinjeksi dengan bakteri E.ictaluri yaitu bagian luar dan bagian dalam, bagian luar yaitu seperti kulit dan sirip adapun bagian dalam yang diamati yaitu ginjal dan hati dapat dilihat pada Tabel. 4 
Yuda Saputra, Syarizal, Safratilofa, dan Edy Barkat Kholidin. Pemberian Tepung Daun Kelor (Moringa oleifera L) Melalui Pakan Sebagai PencegahanTerhadap Infeksi Bakteri Edwarsiella Ictaluri Pada Ikan Patin (Pangasius hypopthalmus)

Tabel. 4 Gejala Klinis Bagian Luar Setiap Perlakuan Ikan Patin (P.hypopthalmus) Percobaan Setelah Diinjeksi Bakteri E.ictaluri

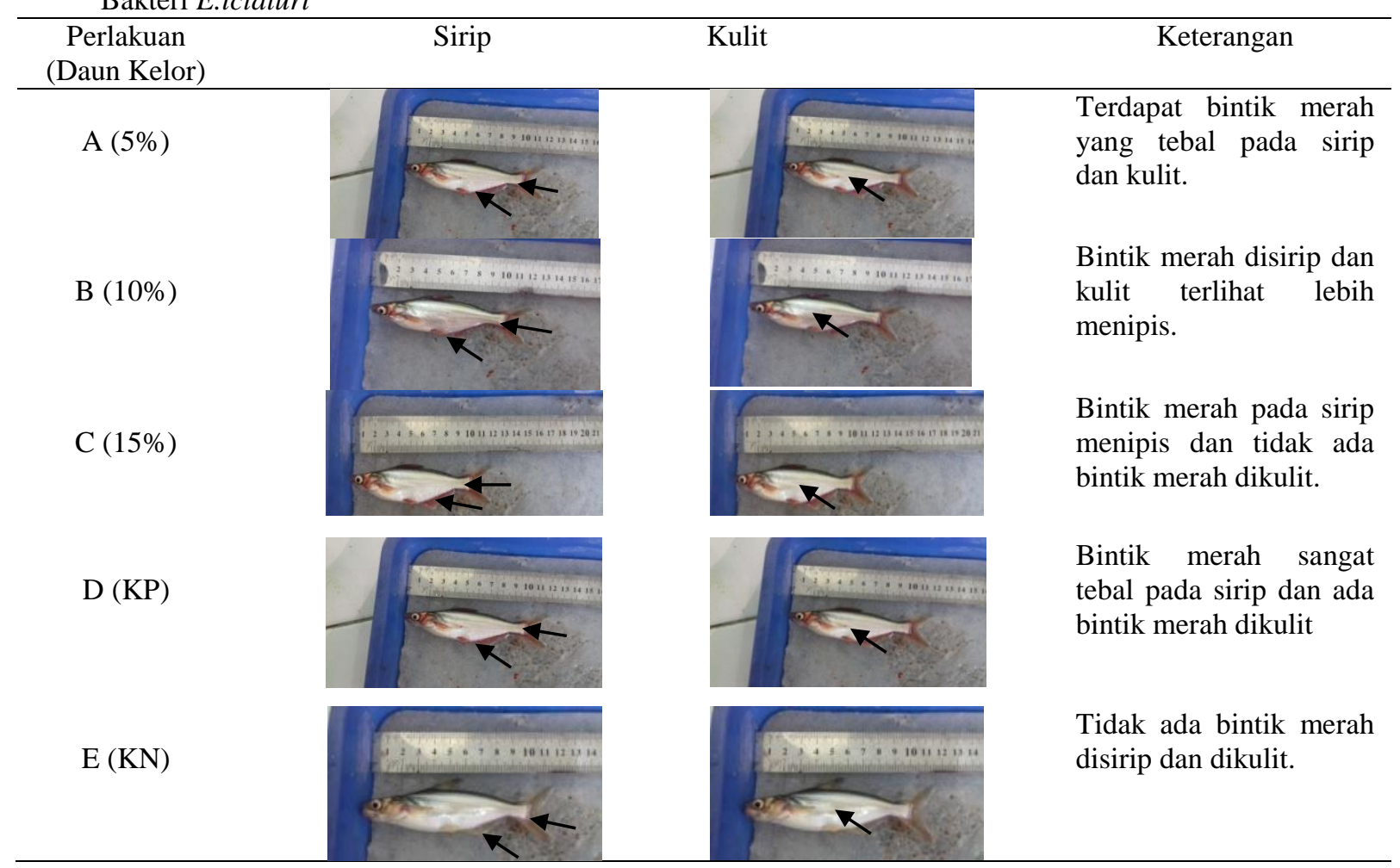

Pada perlakuan E menujukkan bahwa ikan sehat yang tidak terinfeksi bakteri E. ictaluri tidak terdapat binik merah pada bagian sirip dan kulit, sedangkan perlakuan A bintik merah pada sirip dan kulit terlihat tampak jelas, perlakuan B bintik merah terdapat hanya disiripnya saja tetapi bintik merah masih sangat tebal, pelakuan $\mathrm{C}$ bintik merah tedapat pada bagian sirip dan bintik merah lebih sedikit, dan D yang tidak diberikan tepung daun kelor yang diinjeksi dengan bakter E.ictaluri bintik merah pada sirip dan kulit lebih tebal, dikarenakan E. ictaluri merusak pembuluh darah. Menurut Booth dalam Wiwik,(2016), menyatakan bahwa adanya pendarahan dapat disebabkan oleh kerusakan endotel kapiler akibat infeksi yang beredar dipembuluh darah, membuktikan bahwa $E$. ictaluri bersifat merusak pembuluh darah sehingga terjadi pendarahan. Sedangkan gejala klinis bagian dalam yang diamati adalah ginjal dan hati dapat dilihat pada Tabel 5. 
Yuda Saputra, Syarizal, Safratilofa, dan Edy Barkat Kholidin. Pemberian Tepung Daun Kelor (Moringa oleifera L) Melalui Pakan Sebagai PencegahanTerhadap Infeksi Bakteri Edwarsiella Ictaluri Pada Ikan Patin (Pangasius hypopthalmus)

Tabel 5. Gejala Klinis Bagian Dalam Setiap Perlakuan Ikan Patin (P.hypopthalmus) Percobaan Setelah Diinjeksi Bakteri E.ictaluri

$\begin{gathered}\text { Perlakuan } \\ \text { (Daun } \\ \text { Kelor) }\end{gathered}$
A (5\%)

Pada bagian organ hati dan ginjal dapat lihat pada perlakuan E ginjal dan hati tampak merah segar dan terlihat normal karena tidak terinfeksi bakteri E. ictaluri, pada perlakuan A hati tampak membengkak dan bintik putih dihati dan ginjal terlihat tebal limpa pun tampak membesar dan beisi cairan, perlakuan B bintik putih pada hati dan ginjal telihat tebal tetapi tidak setebal pelakuan A, pelakuan $\mathrm{C}$ bintik putih pada hati dan ginjal nampak tipis, dan perlakuan D hati dan ginjal bintik putih sangat tebal dan limpa pun membengkak. Menurut Sakai dalam Wiwik,(2016), menjelaskan bahwa ikan yang terserang bakteri E. ictaluri adanya bercak merah pada bagian kulit, terjadinya pembengkakan abdomen dan organ dalam seperti hati, ginjal, dan limpah serta sebelum mati ikan berenang menggantung hampir vertical dengan kepala dipermukaan air. (Kim dan Park, dalam Wiwik 2016).

\section{Pertumbuhan Ikan}

Pertumbuhan ikan uji dilihat dari bobot mutlak yang diberi pakan tepung daun kelor dapat dilihat di Tabel. 6

Tabel. 6 Bobot Mutlak Rata-Rata Ikan Patin Percobaan Selama Hari Ke 1 Sampai Hari Ke 14 (gram/ekor)

\begin{tabular}{ccc}
\hline Perlakuan (Daun Kelor) & Rerata Pertumbuhan Ikan gram/ekor & Notasi Statistik \\
\hline A (5\%) & 5,47 & a \\
B (10\%) & 5,05 & a \\
C (15\%) & 5,78 & a \\
D (Kontrol) & 5,41 & a \\
\hline
\end{tabular}

Catatan : Huruf yang sama pada kolom notasi menunjukkan tidak berbeda nyata $(\mathrm{P}>0,05)$

Pada Tabel. 6 dapat dilihat dari analisis ragam menunjukan bahwa penggunaan tepung daun kelor ke dalam pakan tidak berpengaruh nyata terhadap pertumbuhan bobot mutlak, namun pertumbuhan bobot mutlak tertinggi yaitu pada perlakuan $\mathrm{C}$ dengan dosis $15 \% / \mathrm{kg}$ pakan, diperoleh bobot mutlak sebesar 5,78/gram, sedangkan pertumbuhan bobot mutlak terendah terdapat pada perlakuan B sebesar 5,05/gram, pertumbuhan bobot mutlak pada perlakuan $\mathrm{A}, \mathrm{B}$, dan $\mathrm{C}$ tidak berbeda nyata dengan perlakuan D. Hal ini disebabkan tepung daun kelor tidak memberikan dampak buruk pada pertumbuhan ikan patin. Menurut Arofa (dalam Hermawan, 2015), menyatakan 
bahwa pertumbuhan ikan dapat terjadi jika jumlah makanan yang melebihi kebutuhan untuk pemeliharaan tubuh. Fujaya, (2000) menjelaskan tidak semua makanan yang dimakan oleh ikan digunakan untuk pertumbuhan. Sebagian besar energi dari makanan digunakan untuk pemeliharaan, sisanya untuk aktivitas, pertumbuhan dan reproduksi. Selain itu pertambahan bobot mutlak tidak signifikan dan belum terlihat berpengaruh, hal ini diduga masa pemeliharaan relatif pendek yaitu selama 14 hari, menurut Elpawati et, al., (2015), menyatakan bahwa pertambahan bobot mutlak pada usia pemeliharaan 7 hari - 14 hari belum terlihat adanya perbedaan penambahan bobot ikan, hal ini disebabkan pertambahan bobot mutlak ikan belum optimum karena masih berada dalam fase awal pembesaran.

\section{Rasio Konversi Pakan}

Konversi pakan yang dimakan oleh ikan patin selama pemeliharaan dapat dilihat pada Tabel. 7.

Tabel 7. Rasio Konversi Pakan Yang Dimakan Ikan Patin Percobaan Selama Penelitian (gram/ekor)

\begin{tabular}{ccc}
\hline Perlakuan (Daun Kelor) & Rerata Rasio Konversi pakan $\%$ & Notasi Statistik \\
\hline A (5\%) & 0,21 & a \\
B (10\%) & 0,19 & a \\
C (15\%) & 0,18 & a \\
D (Kontrol) & 0,17 & a \\
\hline
\end{tabular}

Catatan : Huruf yang berbeda pada kolom notasi menunjukkan berbeda nyata $(\mathrm{P}>0,05)$

Pada Tabel. 6 dapat dilihat dari setiap perlakuan mempunyai nilai tersendiri dan nilai terendah ada pada perlakuan D sebesar 0,17/gram, dan nilai rasio konversi pakan tertinggi ada pada perlakuan A sebesar 0,21/gram, tapi hasil pada setiap perlakuan tidak berbeda nyata dapat dilihat semua perlakuan terdapat subtitel yang sama ini menunjukkan bahwa rasio konversi pakan menggunakan tepung daun kelor tidak berbeda nyata, dan pemberian pakan pada penelitian ini secara ad satiation, rasio konversi pakan ini menunjukkan bahwa pemberian tepung daun kelor baik pemeliharaan karena rerata sebesar 0,18/gram, rasio konversi pakan menunjukkan bahwa pada penelitian ini rasio konversi pakan sangat bagus. Menurut Tahapari et, al., (2008), menyatakan bahwa semakin tinggi rasio konversi pakan menunjukkan semakin tidak efisien pakan yang digunakan.

\section{Kualitas Air}

Data hasil uji parameter kualitas Air untuk pemeiliharaan dan kelangsungan hidup ikan patin ( Pangasionodon hypopthalmus) disajikan dalam Tabel. 8 berikut:

Tabel. 8 Kualitas Air Pada Ikan Patin Percobaan Selama Penelitian :

\begin{tabular}{|c|c|c|c|c|c|c|c|c|c|c|c|c|c|}
\hline \multirow{3}{*}{ No. } & \multirow{3}{*}{ Parameter } & \multirow{3}{*}{ Satuan } & \multicolumn{11}{|c|}{ Hasil Uji } \\
\hline & & & \multicolumn{3}{|c|}{ A } & \multicolumn{2}{|c|}{ B } & \multicolumn{2}{|c|}{$\mathrm{C}$} & \multicolumn{2}{|c|}{ D } & \multicolumn{2}{|c|}{ E } \\
\hline & & & 1 & 2 & 3 & 2 & 3 & 2 & 3 & 2 & 3 & 2 & 3 \\
\hline 1 & Suhu & ${ }^{\circ} \mathrm{C}$ & 27 & 26,6 & 26,5 & 26,3 & 26,5 & 26,5 & 26,4 & 26,6 & 26,4 & - & 26,5 \\
\hline 2 & DO & $\mathrm{mg} / \mathrm{L}$ & 8,0 & 8,0 & 8,1 & 8,0 & 8,1 & 8,0 & 8,0 & 8,0 & 8,1 & - & 8,2 \\
\hline 3 & $\mathrm{pH}$ & - & 6,5 & 6,8 & 6,6 & 6,4 & 6,7 & 6,6 & 6,9 & 6,3 & 6,7 & - & 6,8 \\
\hline 4 & Amonia & $\mathrm{mg} / \mathrm{L}$ & 0,01 & 0,04 & 0,08 & 0,06 & 0,08 & 0,05 & 0,09 & 0,06 & 0,08 & - & 0,08 \\
\hline
\end{tabular}

Keterangan :

$1=$ "Pengecekan awal penelitian

$2=$ *Pengecekan tengah penelitian

$3={ }^{*}$ Pengecekan akhir penelitian

Berdasarkan data pengukuran parameter kualitas air yang tergambar pada Tabel. 8 diatas dapat diketahui bahwa suhu, DO, pH yang dihasilkan dalam pemeliharaan ikan patin pada setiap perlakuan masih berada dalam ambang batas kualitas air yang normal untuk budidaya. Suhu sangat berpengaruh terhadap kehidupan dan pertumbuhan ikan. Secara umum, laju pertumbuhan meningkat sejalan dengan kenaikan suhu, dapat menekan kehidupan ikan bahkan menyebabkan kematian bila kenaikan suhu naik drastis (Kordi dan Tancung, 2005).

Sedangkan amonia selama waktu penelitian menunjukkan nilai yang cukup bervariasi yaitu $0,01 \mathrm{mg} / \mathrm{L}$ pada pertengahan penelitian meningkat hingga $0,06 \mathrm{mg} / \mathrm{L}$ dan pada akhir penelitian meningkat hingga 0,08 mg/L. Kadar amoniak tergolong tinggi, hal ini diduga karena meningkatnya metabolisme ikan untuk melawan serangan bakteri dalm tubuh ikan. Menurut Floyd dan Watson (dalam M. Ridwan, 2019), bahwa amonia adalah produksi metabolisme yang utama dari ikan, yang dikeluarkan melalui urine dan insang. Menurut effendi (2003), konsentrasi amonia total diperairan yang dapat diterima oleh ikan berada pada $0,2 \mathrm{mg} / \mathrm{L}$. 


\section{KESIMPULAN}

Berdasarkan hasil penelitian tentang pemberian tepung daun kelor (Moringa oliefera L) melalui pakan sebagai pencegahan terhadap infeksi bakteri Edwarsiella ictaluri pada ikan patin (Pangasius hypopthalmus), selama penelitian dapat menarik kesimpulan bahwa penambahan tepung daun kelor $15 \% / \mathrm{kg}$ pakan dapat mencegah terjadinya infeksi bakteri E.ictaluri pada ikan patin dengan tingkat kelangsungan hidup tertinggi mencapai 66,67\%, pertumbuhan ikan 5,78 gram/ekor, dan konversi pakan 0,18\%/kg pakan dengan gejala klinis yang ringan.

\section{DAFTAR PUSTAKA}

Emilda 2018, Efek Senyawa Bioaktif Kayu Manis Cinnamomum burmanii (NEES EX.BL.) Terhadap Diabetes Melitus

Effendie, H. 2003. Telaah Kualitas Air. Kanisius. Bogor. 246 hal.

Elpawati, Diana R. P, Nani R, 2015, Aplikasi Effective Microorganisme $10\left(\mathrm{Em}_{10}\right)$ Untuk Pertumbuhan Ikan Lelel Sangkuriang (Clarias gariepinus Var. Sangkuriang) Di Kolam Budidaya Lele Jombang, Tangerang, Jurnal Biologi Vo; 8 Nomor 1.

Jadmiko. D, 2016. Performa benih ikan patin siam Pangasianodon hypophthalmus (Sauvage, 1878) dan pasupati (Pangasius sp.) dengan padat penebaran yang berbeda pada pendederan sistem resirkulasi

Lusi L.R.H Dima, 2016. Uji Aktivitas Antibakteri Ekstrak Daun Kelor (Moringa Oleifera L.) Terhadap Bakteri Escherichia Coli Dan Staphylococcus Aureus.

Ridwan M, 2019 Skripsi Efektifitas Pemberian Jenis Pakan Nabati Tanaman Darat Terhadap Pertumbuhan dan Kelangsungan Hidup Benih Ikan Koan (Ctenopharyngodon idella), $\quad 26-27$.

Oluduro, and Anthonia, O, 2011. Evaluation of Antimicrobial Properties and Nutritional Potentials of Moringa oleifera Lam. Leaf in South-Western Nigeria. Malaysian Journal of Microbiology., 8, 59-60.

Safratilofa, Sugihartono.M. 2018. Uji Daya Hambat Bawang Hutan Eleutherine Palmifolia Dengan Metode Ekstraksi Berbeda Terhadap Pertumbuhan Bakteri Aeromonas Hydrophila., Vol. 3 No. 2 Tahun 2018 Hal. 56 $-63$.

Valent AF. 2017. Potensi Ekstrak Etanol Daun Kelor (Moringa oleifera) Terhadap Penurunan Kadar Histamin Pada Ikan Lemuru (Sardinella longiceps)

Wahjuningrum D, Astrini R, Setiawati M. 2012. Pencegahan infeksi Aeromonas hydrophila pada benih ikan lele (Clarias sp.) yang berumur 11 hari menggunakan bawang putih Allium sativum dan meniran Phyllanthus

Wiwik S, Agustin I, Fachriyan H P. 2016 Kajian Patogenisitas bakteri Edwarsiella ictaluri pada ikan patin Pangasianodon hypopthalmus, $99-107$. 